\title{
Intersection Performance Study Using PTV VISTRO (Case Study : Jember)
}

\author{
Willy Kriswardhana and Sonya Sulistyono
}

\begin{abstract}
Vistro is an abbreviation of Vision Traffix and Optimization developed by PTV AG Germany. Vistro is one of the transportation applications developed for traffic engineering. This application was introduced first the end of 2012 and entered in the Asia Pacific market including in Indonesia in early 2013. Vistro as one of the transportation applications present to solve the impact evaluation of regional development, evaluation of $\operatorname{LoS}$ (level of service) an intersection, and create reports in the form of tables and drawings. Although there have been many study that use Vistro, there is a lack of a coherent and summary review. To address this issue, we have conducted a research related to the intersection performance using Vistro. Systematic reviews are used to find and classify all existing and available literature in a certain field. These papers were further analysed and categorised based on their research, contribution, and evaluation. The conclusion shows that Vistro was able to reduce the delay of intersection. As a software of traffic impact analysis, Vistro has some useful features to do four steps modelling of transportation. Some papers indicate that Vistro has a random result for un-signalised intersection.
\end{abstract}

Index Terms - vistro, intersection.

\section{INTRODUCTION}

Incre ncreasing demand for mobility makes decision makers face greater challenges. This phenomenon is more present in the field of road transport. Strategies in traffic regulations show clear direction on efficiency improvement without limiting transportation demand. This strategy applies efficiency to improve the capacity of transport infrastructure by updating traffic controls to reduce transportation problems such as congestion, pollution, and noise. [1]

Many authors [2,3] claim that the continuous improvement and upgrading of transport systems is needed to meet the expectations of tourists, suppliers and customers. To meet these requirements, technology-based transport solutions, infrastructure and policy-based needs need to be implemented in the transport system. Many

W. Kriswardhana is with the Department of Civil Engineering, University of Jember, Jember, East Java, Indonesia (e-mail: willy.teknik@unej.ac.id)

S. Sulistyono is with the Department of Civil Engineering, University of Jember, Jember, East Java, Indonesia and Department of Civil Engineering, Brawijaya Unisersity, East Java, Indonesia. authors report a variety of sophisticated and native solutions that are applied in various countries that are often developed as a set of combined tools that are a comprehensive transportation project. $[3,4,5,6]$.

Application of the model as a tool makes it possible to predict the consequences of decisions such as the necessity for diversion of currents or to compose a rational variant of the modernization of infrastructure. In addition, the traffic model allows us to show changes in the distribution of traffic flows. Traffic models can be prepared for different areas, including districts, cities, agglomerations, provinces, countries or even continents. Less detailed analysis when modeling a larger area is strongly related to availability and limited research tools [7]. The intermediate simulation model describes traffic at a high aggregation level, as a uniform traffic flow. They are based on a deterministic relationship between the amounts that characterize traffic flows such as: volume, speed and density. Intermediate simulations have been developed to model the overall network and / or transportation system. [8]

Nowadays, many software have been developed to facilitate traffic analysis and transportation planning, one of the example is PTV Vistro. Through an in-depth experiment, it is explicitly verified that the estimated delay value may depend on the choice of the analytical tool. Use of calibrated devices using simulation models is closest to measured values in the field. [9]. According to Septiawan [10], green time optimization using PTV VISTRO can reduce delays at the signalized intersection. The amount of delay can reach $26.23 \%$. The development of traffic databases in the medium can be the basis in the selection of alternative solutions to problems at the intersection so as to create a smart transportation infrastructure and environmentally friendly.

\section{ReCEnT Study of PTV Vistro}

\section{A. Indonesian Highway Capacity Manual 1997}

\section{B. PTV Vistro concept}

PTV Vistro is a software in traffic performance analysis in Indonesia. PTV Vistro was developed by PTV group and released in January 2013. Currently, the use of PTV Vistro in Indonesia has started to be implemented in several regions of Indonesia, such as Jakarta Provincial Government, Jember University, and Consultant in Bali. 
The calculation of intersection performance using PTV Vistro is done by Highway Capacity Manual (HCM) method 2010. As for the calculation of roundabout using Kimberly method and Intersection Capacity Utilization 1 and 2.

This software make it easier to evaluate the impact of regional development, evaluate the Level of Service (LoS) of an intersection, and create reports in the form of tabls and drawings. In addition, this software can also be used 1 perform traffic impact analysis. Traffic impact analys includes traffic generation (trip generation, distribution an assignment), traffic management scenarios, evaluation ar testing in mitigation, provision of comprehensive repor and traffic previews for future development.

Delay in seconds per vehicle is the most important traffic operational index to evaluate the level of intersection service. Accurate delay calculations are required because they are used as a basic quantitative proof for investment decision making at a traffic facility. Thus, various analytical tools, including CORSIM, SYNCHRO, T7F, VISTRO, etc. have been utilized so far. However, each analytical tool can use a unique methodology to calculate delays. Therefore, the estimated value of the delay may differ from the selection of the analytical tool, which has made it difficult for the traffic engineer to make a solid assessment. This study was initiated to verify the feasibility of various analytical tools, including HCM, CORSIM, SYNCHRO, T7F, VISTRO methodologies in calculating the delay by comparing the estimated delays with measurable ones in the field. Some selected devices produce very different delays. The estimated delay value using a calibrated CORSIM model is approaching with a measured delay in the field. [9]

\section{Recent Study of PTV VISTRO on Intersection Performance}

Only a few studies have used PTV VISTRO to calculate the performance of intersections and intersections. One of the features contained in this software is optimization. The automated optimization using PTV Vistro aims to balance the value of delay and degree of saturation on each of the intersection sides in one intersection. The phase optimization decreases the average delay rate by $64 \%$ and the degree of saturation of $17 \%$ for Basuki Rahmat signalized intersection at peak hours of attraction. At MH Thamrin signalized intersection, average delay decreased by $76 \%$ and degree of saturation $20 \%$.

Sauri, et al. [11] conducted a study by comparing the performance of unisgnalized intersections and signalized intersections calculated using KAJI and PTV VISTRO software. At the un-signalized intersection, it is indicated that the performance of PTV Vistro and KAJI have different pattern and different result. At signalized intersection, PTV Vistro and KAJI performance results show the same pattern, but the delay number produced by PTV Vistro is smaller than KAJI. The difference in performance results between PTV Vistro and the MKJI (Manual Kapasitas Jalan Indonesia/ Indonesian Highway Capacity Manual) method does not have a substantial difference. PTV Vistro and MKJI produced almost the same pattern, but the value of
PTV Vistro delay tends to be bigger than MKJI performance calculation result with difference of analysis result about 5\%. [12].

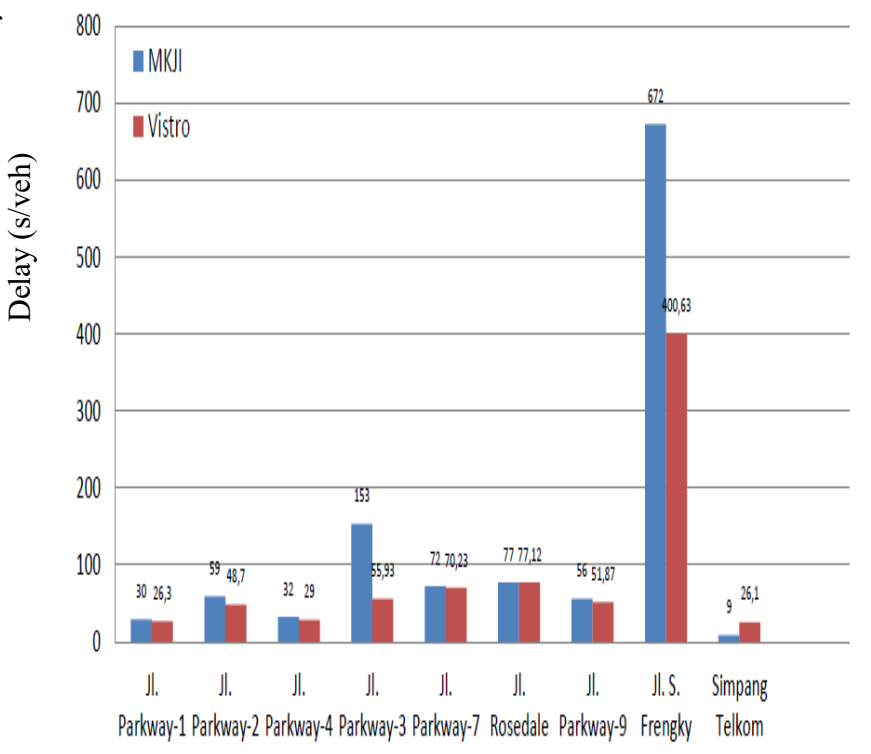

Fig. 1. Comparison value of delay ( $\mathrm{s} / \mathrm{veh})$

Source : Rifai, et.al. (2014)

The same study compares between PTV Vistro and Manual MKJI calculation results. Kriswardhana, et al. [13] concluded that the calculation of un-signalized intersections using PTV Vistro tends to be random. Arifin, et al. (2016) states that the use of PTV Vistro software in transportation planning can help in storing the input data database intersection for use at other times. The availability of scenario drafting facilities, will assist in analyzing different conditions on the road network of reviews. In addition, Ronaldo [14] stated that IHCM is not based on mixed traffic condition. He indicated that IHCM 1997 gave significantly different results compared to the observation data in almost detector in terms of flow. While the micro-simulation using AIMSUN gave similar results compared to the observation data.

\section{Meso-Simulation Using PTV Vistro}

\section{A. Building PTV VISTRO network}

Several steps to build PTV VISTRO network are listed below:

1. The first step in PTV Vistro modelling is to create a road network. To create a road network this required a location map. PTV Vistro has provided several map options, they are Bing Maps and Open Street Map. We can find the location of the study and determine the intersection point to be reviewed. In this study, the presentation of maps using Open Street Map.

2. The second step is to make a base scenario. Initial scenario used as a reference in doing traffic engineering. Preliminary scenario creation requires data on traffic conditions, geometric approaches, traffic settings, and 
cycle times. In making base scenario there are some data that must be inputted.

a. Setting up the intersection. In performing PTV Vistro modelling, all setting data to calculate the intersection performance should be completed. Geometric data intersections such as path width, lane settings, and median existence must be completed. The input data is filled correctly and adjusted to the condition in the field.

b. Volume data input. In addition to geometric data intersections, the initial data that should be included in PTV Vistro modelling is traffic volume data. At PTV Vistro, the volume of traffic used is volume in Passenger Car Unit (pcu/ hour). Volume data input on PTV Vistro is different from MKJI. If the MKJI input volume data is divided into three types of vehicles, then the PTV Vistro input volume data is only classified based on the movement of the turn on each lane regardless of the type of vehicle. The volume data that has been entered will be directly connected to the initial database such as generation, distribution, and loading. The growth data should also be included if it is to plan for future modelling.

c. Traffic control. In PTV Vistro the calculation of the performance of the intersection can be calculated by using some rules that have been provided in PTV Vistro such as HCM 2010, HCM 2000, and ICU. HCM 2000 and HCM 2010 methods can be used for both signalized and un-signalized intersections, while ICU methods are used for roundabouts. In this study the method used to calculate the performance of the intersection is HCM 2010.

TABLE I

PARAMETER DIFFRENCES

\begin{tabular}{|c|c|c|c|}
\hline No & Parameter & $\begin{array}{l}\text { PTV } \\
\text { Vistro }\end{array}$ & MKJI \\
\hline 1 & Volume & pcu/hour & $\begin{array}{l}\text { Classified into } \\
\text { three types of } \\
\text { vehicle }\end{array}$ \\
\hline 2 & $\begin{array}{l}\text { Side } \\
\text { friction }\end{array}$ & $\begin{array}{c}\text { Not } \\
\text { mentioned }\end{array}$ & $\begin{array}{l}\text { Classified into } \\
\text { three levels of } \\
\text { side friction, } \\
\text { based on roadside } \\
\text { environment }\end{array}$ \\
\hline 3 & Methods & $\begin{array}{c}\text { HCM } \\
2000, \\
\text { HCM } \\
2010, \\
\text { ICU, etc. }\end{array}$ & $\begin{array}{c}\text { Indonesia } \\
\text { Highway } \\
\text { Capacity Manual }\end{array}$ \\
\hline
\end{tabular}

\section{B. Example of Simulation Result}

There are 22 intersections in Jember which are the case studies in the simulation. The intersection was built and analyzed at PTV VISTRO. In this article, only the simulation results in the performance of the intersections are displayed. The intended intersection performance is delay (det/ veh) and Level of Service (LOS)
TABLE II

INTERSECTION ANALYSIS SUMMARY

\begin{tabular}{|c|c|c|c|c|}
\hline No & $\begin{array}{c}\text { Intersection } \\
\text { name }\end{array}$ & Control type & $\begin{array}{l}\text { Delay } \\
(\mathrm{s} / \mathrm{veh})\end{array}$ & LOS \\
\hline 1 & KFC & Two-way stop & 41.98 & $\mathrm{D}$ \\
\hline 2 & Al-Amin & Two-way stop & 3.15 & A \\
\hline 3 & Kenanga & Two-way stop & 6.95 & A \\
\hline 4 & Pendopo & Two-way stop & 302.5 & $\mathrm{~F}$ \\
\hline 5 & BRI & Two-way stop & 8.87 & A \\
\hline 6 & Ciliwung & All-way stop & 20.82 & $\mathrm{C}$ \\
\hline 7 & $\begin{array}{c}\text { Gatot } \\
\text { Subroto }\end{array}$ & Two-way stop & 111.6 & $\mathrm{~F}$ \\
\hline 8 & Tembakan & All-way stop & 800.5 & $\mathrm{~F}$ \\
\hline 9 & GNI & Two-way stop & 23.78 & $\mathrm{C}$ \\
\hline 10 & $\begin{array}{c}\text { Dr. } \\
\text { Soetomo }\end{array}$ & Two-way stop & 6.39 & A \\
\hline 11 & $\begin{array}{c}\text { Pasar } \\
\text { Tanjung }\end{array}$ & Signalized & 311.1 & $\mathrm{~F}$ \\
\hline 12 & $\begin{array}{l}\text { Untung } \\
\text { Suropati }\end{array}$ & Two-way stop & 3.89 & A \\
\hline 13 & Matahari & Two-way stop & 2.35 & A \\
\hline 14 & Istana & Two-way stop & 12.81 & $\mathrm{~B}$ \\
\hline 15 & Polres & Roundabout & 13.09 & $\mathrm{~B}$ \\
\hline 16 & Tidar & All-way stop & 420 & $\mathrm{~F}$ \\
\hline 17 & Prosalina & All-way stop & 527.7 & $\mathrm{~F}$ \\
\hline 18 & Jarwo & Signalized & 2360 & $\mathrm{~F}$ \\
\hline 19 & Mastrip & Signalized & 513 & $\mathrm{~F}$ \\
\hline 20 & Argopuro & Signalized & 767 & $\mathrm{~F}$ \\
\hline 21 & $\begin{array}{c}\text { Bundaran } \\
\text { DPR }\end{array}$ & Roundabout & 24.6 & $\mathrm{C}$ \\
\hline
\end{tabular}

The result of intersection performance shows that Jarwo, Mastrip, and Argopuro signalized intersections have poor performance. While at the un-signalized intersection, Tembakan and Prosalina is an intersection has a poor performance. 


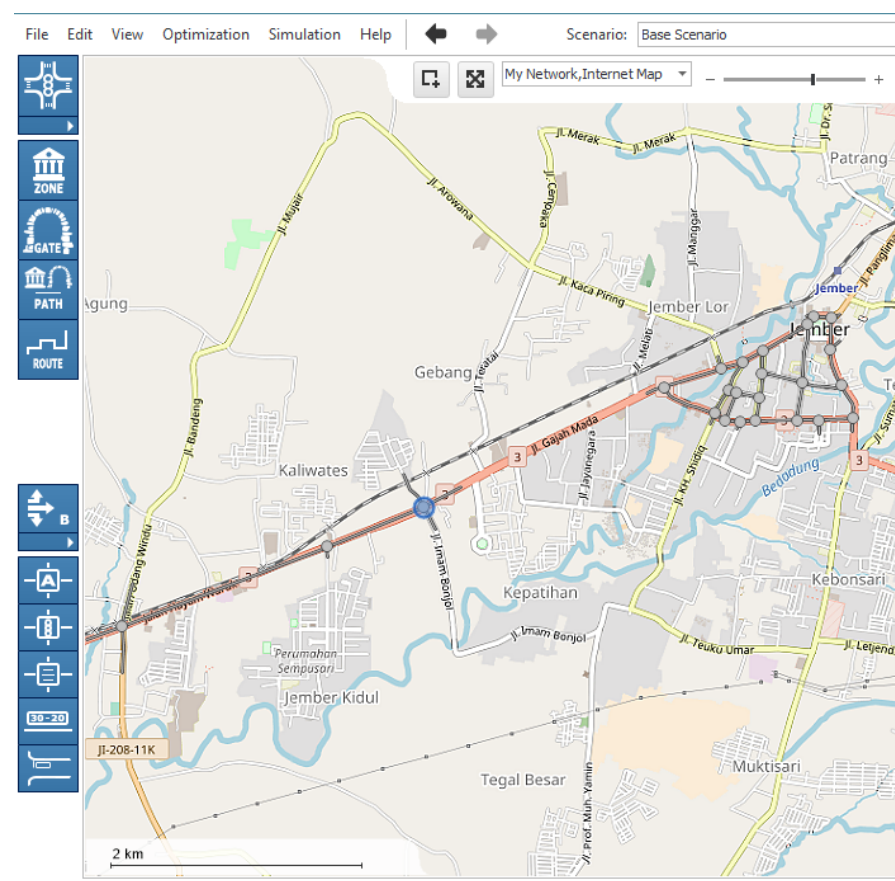

Fig. 2. Display in PTV VISTRO. A. Building PTV VISTRO network below:

Several steps to build PTV VISTRO network are listed

3. The first step in PTV Vistro modelling is to create a road network. To create a road network this required a location map. PTV Vistro has provided several map options, they are Bing Maps and Open Street Map. We can find the location of the study and determine the intersection point to be reviewed. In this study, the presentation of maps using Open Street Map.

4. The second step is to make a base scenario. Initial scenario used as a reference in doing traffic engineering. Preliminary scenario creation requires data on traffic conditions, geometric approaches, traffic settings, and cycle times. In making base scenario there are some data that must be inputted.

d. Setting up the intersection. In performing PTV Vistro modelling, all setting data to calculate the intersection performance should be completed. Geometric data intersections such as path width, lane settings, and median existence must be completed. The input data is filled correctly and adjusted to the condition in the field.

e. Volume data input. In addition to geometric data intersections, the initial data that should be included in PTV Vistro modelling is traffic volume data. At PTV Vistro, the volume of traffic used is volume in Passenger Car Unit (pcu/ hour). Volume data input on PTV Vistro is different from MKJI. If the MKJI input volume data is divided into three types of vehicles, then the PTV Vistro input volume data is only classified based on the movement of the turn on each lane regardless of the type of vehicle. The volume data that has been entered will be directly connected to the

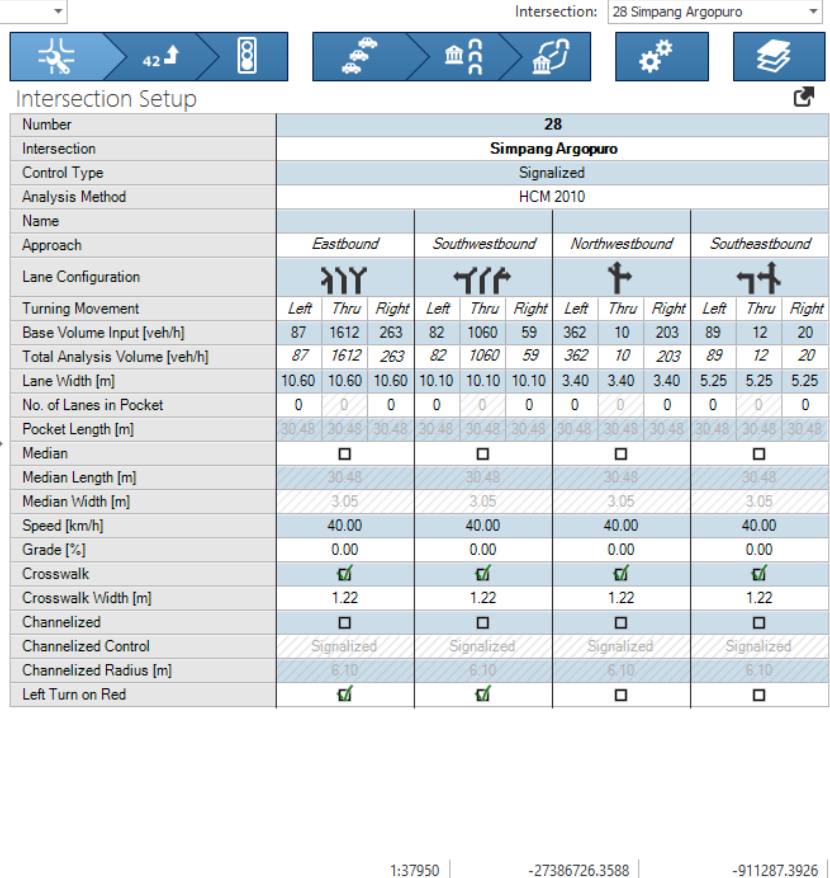

initial database such as generation, distribution, and loading. The growth data should also be included if it is to plan for future modelling.

f. Traffic control. In PTV Vistro the calculation of the performance of the intersection can be calculated by using some rules that have been provided in PTV Vistro such as HCM 2010, HCM 2000, and ICU. HCM 2000 and HCM 2010 methods can be used for both signalized and un-signalized intersections, while ICU methods are used for roundabouts. In this study the method used to calculate the performance of the intersection is HCM 2010.

\section{B. Example of Simulation Result}

There are 22 intersections in Jember which are the case studies in the simulation. The intersection was built and analyzed at PTV VISTRO. In this article, only the simulation results in the performance of the intersections are displayed. The intended intersection performance is delay (det/ veh) and Level of Service (LOS) 
TABLE II

INTERSECTION ANALYSIS SUMMARY

\begin{tabular}{ccccc}
\hline No & $\begin{array}{c}\text { Intersection } \\
\text { name }\end{array}$ & Control type & $\begin{array}{c}\text { Delay } \\
(\mathrm{s} / \mathrm{veh})\end{array}$ & LOS \\
\hline 1 & KFC & Two-way stop & 41.98 & $\mathrm{D}$ \\
\hline 2 & Al-Amin & Two-way stop & 3.15 & $\mathrm{~A}$ \\
\hline 3 & Kenanga & Two-way stop & 6.95 & $\mathrm{~A}$ \\
\hline 4 & Pendopo & Two-way stop & 302.5 & $\mathrm{~F}$ \\
\hline 5 & BRI & Two-way stop & 8.87 & $\mathrm{~A}$ \\
\hline 6 & Ciliwung & All-way stop & 20.82 & $\mathrm{C}$ \\
\hline 7 & $\begin{array}{c}\text { Gatot } \\
\text { Subroto }\end{array}$ & Two-way stop & 111.6 & $\mathrm{~F}$ \\
\hline 8 & Tembakan & All-way stop & 800.5 & $\mathrm{~F}$ \\
\hline 9 & GNI & Two-way stop & 23.78 & $\mathrm{C}$ \\
\hline 10 & $\begin{array}{c}\text { Dr. } \\
\text { Soetomo }\end{array}$ & Two-way stop & 6.39 & $\mathrm{~A}$ \\
\hline 11 & $\begin{array}{c}\text { Pasar } \\
\text { Tanjung }\end{array}$ & Signalized & 311.1 & $\mathrm{~F}$ \\
\hline & & & &
\end{tabular}

\begin{tabular}{ccccc}
\hline 12 & $\begin{array}{c}\text { Untung } \\
\text { Suropati }\end{array}$ & Two-way stop & 3.89 & $\mathrm{~A}$ \\
\hline 13 & Matahari & Two-way stop & 2.35 & $\mathrm{~A}$ \\
\hline 14 & Istana & Two-way stop & 12.81 & $\mathrm{~B}$ \\
\hline 15 & Polres & Roundabout & 13.09 & $\mathrm{~B}$ \\
\hline 16 & Tidar & All-way stop & 420 & $\mathrm{~F}$ \\
\hline 17 & Prosalina & All-way stop & 527.7 & $\mathrm{~F}$ \\
\hline 18 & Jarwo & Signalized & 2360 & $\mathrm{~F}$ \\
\hline 19 & Mastrip & Signalized & 513 & $\mathrm{~F}$ \\
\hline 20 & Argopuro & Signalized & 767 & $\mathrm{~F}$ \\
\hline 21 & $\begin{array}{c}\text { Bundaran } \\
\text { DPR }\end{array}$ & Roundabout & 24.6 & $\mathrm{C}$ \\
\hline
\end{tabular}

The result of intersection performance shows that Jarwo, Mastrip, and Argopuro signalized intersections have poor performance. While at the un-signalized intersection, Tembakan and Prosalina is an intersection has a poor performance.

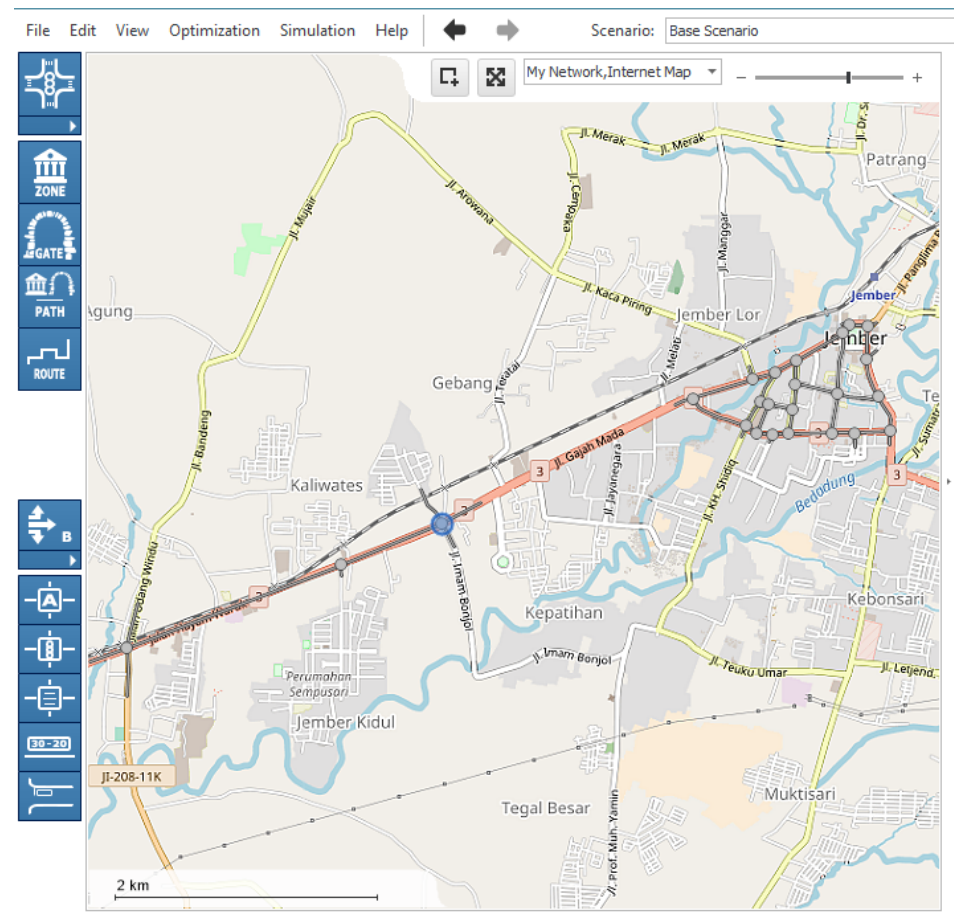

Fig. 2. Display in PTV VISTRO.

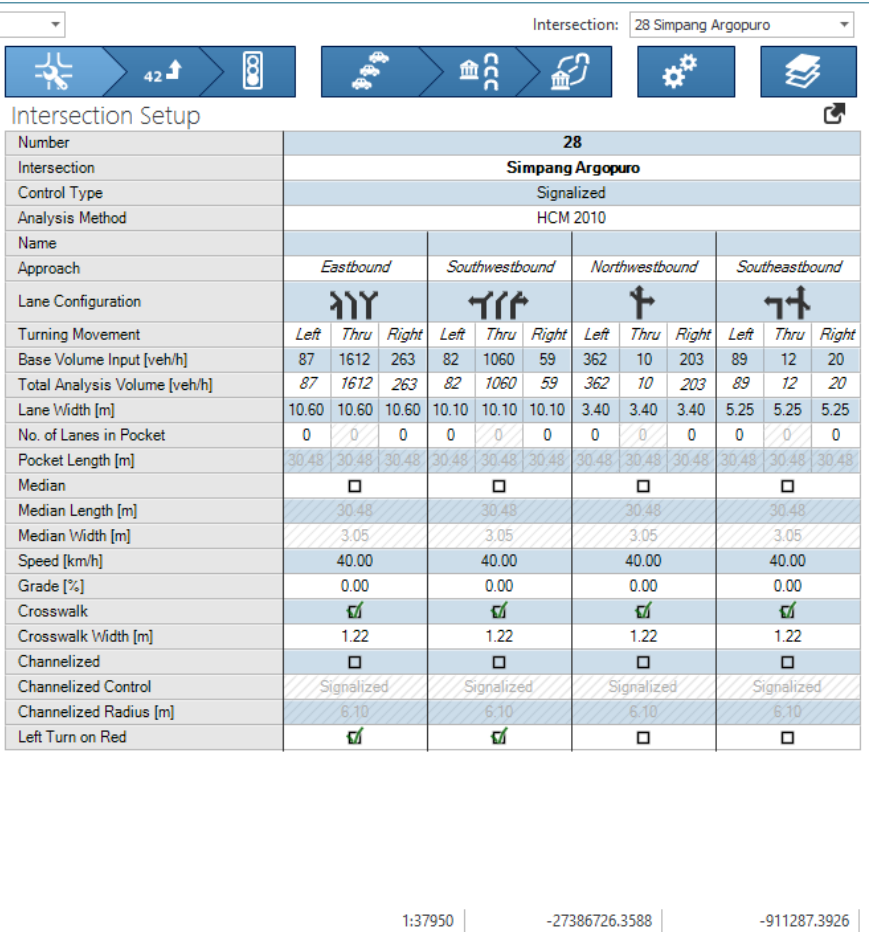

\section{CONCLUDING REMARKS}

It can be concluded that the development of middle-level traffic modeling database using PTV VISTRO can provide accurate information about the performance of the intersection, both signalized and un-signalized. This modelling can be used in baseline data in other studies such as traffic impact analysis, traffic alteration, intersection performance improvement plan, and prediction of urban intersection performance in the future. This can certainly be useful for 
researchers and policy makers. This traffic modelling database can only be accessed using PTV VISTRO software, where the Transportation Laboratory of the Faculty of Engineering University of Jember already has an official license for the use of the software.

Considering the future works, MKJI, which announced in 1997, should be improved in intersection calculation performance. As we know, Indonesia traffic has changed in past years. In addition, PTV Vistro, which does not have any calibration methods developed, should be the future works for any related area of research.

\section{REFERENCES}

[1] F. Meszaros, and A. Torok, "Theoritical Investigation of Emission and Delay Based Intersection Controlling and Synchronizing in Budapest," Perioda Polytechnica Transportation Engineering, 37-42, 2014.

[2] D. Hensher, and K. Button, "Handbook of Transport Modelling". Oxford: Elsevier, 2000.

[3] V. Vuchic, "Urban Transit Systems and Technology," John Wiley \& Sons, 2007.

[4] D. Novak, J. Sullivan, J., and D Scott, "A Network-based Approach for Evaluating and Ranking Transportation Roadway Projects," Applied Geography, 498-506, 2012.

[5] K. Small, and J. Gomez-Ibanez, "Urban Transportation, Handbook of Regional and Urban Economics," 1999.

[6] J. Zak, and T. Thiel, "Multiple Criteria Evaluation of the Development Scenarios of the Mass Transit System," The 9th World Conference on Transport Research, Seoul, 2001.

[7] M. Jacyna, M. Wasiak, M. Klodawski, and P. Golebiowski, “ Modelling of Bicycle Traffic in the Cities Using VISUM," 10th International Scientific Conference Transbaltica, Procedia Engineering, pp. 435-441, 2017.

[8] S. Nocera, M. Basseo, and F. Cavallaro, F., "Micro and Macro Modelling Approaches for the Evaluation of the Carbon Impacts of Transportation," 3rd Conference on Sustainable Urban Mobility, Volos: Transportation Research Procedia, pp. 146-154, 2017.

[9] Y. Ilsoo, O.A.H Cheol, K. Kyunghyun, H. Eum, N. W. Kang, and J. E. Yoon, "Performance Comparison of Signalized Intersections Analysis Tools in Estimating Control Delays," International Journal of Highway Engineering, Vol. 16 No. 5, 109-119, 2014.

[10] D. Septiawan, S. Sulistyono, S., and J. Irawan, "Traffic Impact Analysis On The Development Of Jember Icon Using PTV Vistro," The 18th FSTPT International Symposium, Bandar Lampung, pp. 876-886, 2015

[11] S. Sauri, S. Sulistyono, and A. Hasanuddin, "Analisis Kinerja Simpang Menggunakan Perangkat Lunak KAJI dan PTV Vistro ( Studi Kasus: Simpang Bersinyal dan Tak Bersinyal Perkotaan Jember)," The 17th FSTPT International Symposium, Jember, pp. 1498-1507, 2014.

[12] S. Sulistyono, W. Kriswardhana, N.N Hayati, and I. Destiyanto, "Perbandingan Kinerja Simpang Menggunakan PTV VISTRO dan MKJI Pada Kawasan Perkotaan Lumajang," The 19th FSTPT International Symposium, Yogyakarta, 2016.

[13] W. Kriswardhana, N.N. Hayati, and D.D.Nuraini, "Manajemen Rekayasa Lalu Lintas Central Business District Area Segitiga Emas Kabupaten Jember Menggunakan PTV VISTRO," The 19th FSTPT International Symposium, Yogyakarta, 2016.

[14] A. Ronaldo, "Comparison of the Micro-simulation Software AIMSUN \& IHCM-1997 for Highway Traffic Performance Analysis," Civil Engineering Forum Volume XXI/3 - September, 2012. 